\title{
OPTIMIZING PORTFOLIO RETURN WITH NAÏVE DIVERSIFICATION-BASED MODELLING
}

\author{
Baiq Nurul Suryawati ${ }^{1}$, Laila Wardani ${ }^{2}$, Muttaqillah ${ }^{3}$, Iwan Kusmayadi ${ }^{4}$ \\ ${ }^{1}$ Faculty of Economics and Business, Mataram University \\ Email : nurul.suryawati@unram.ac.id \\ ${ }^{2}$ Faculty of Economics and Business, Mataram University \\ Email : elawardani_mtr@yahoo.com \\ ${ }^{3}$ Faculty of Economics and Business, Mataram University \\ Email : mutaqilahei@yahoo.com \\ ${ }^{4}$ Faculty of Economics and Business, Mataram University \\ Email : iwankusmayadi304@gmail.com
}

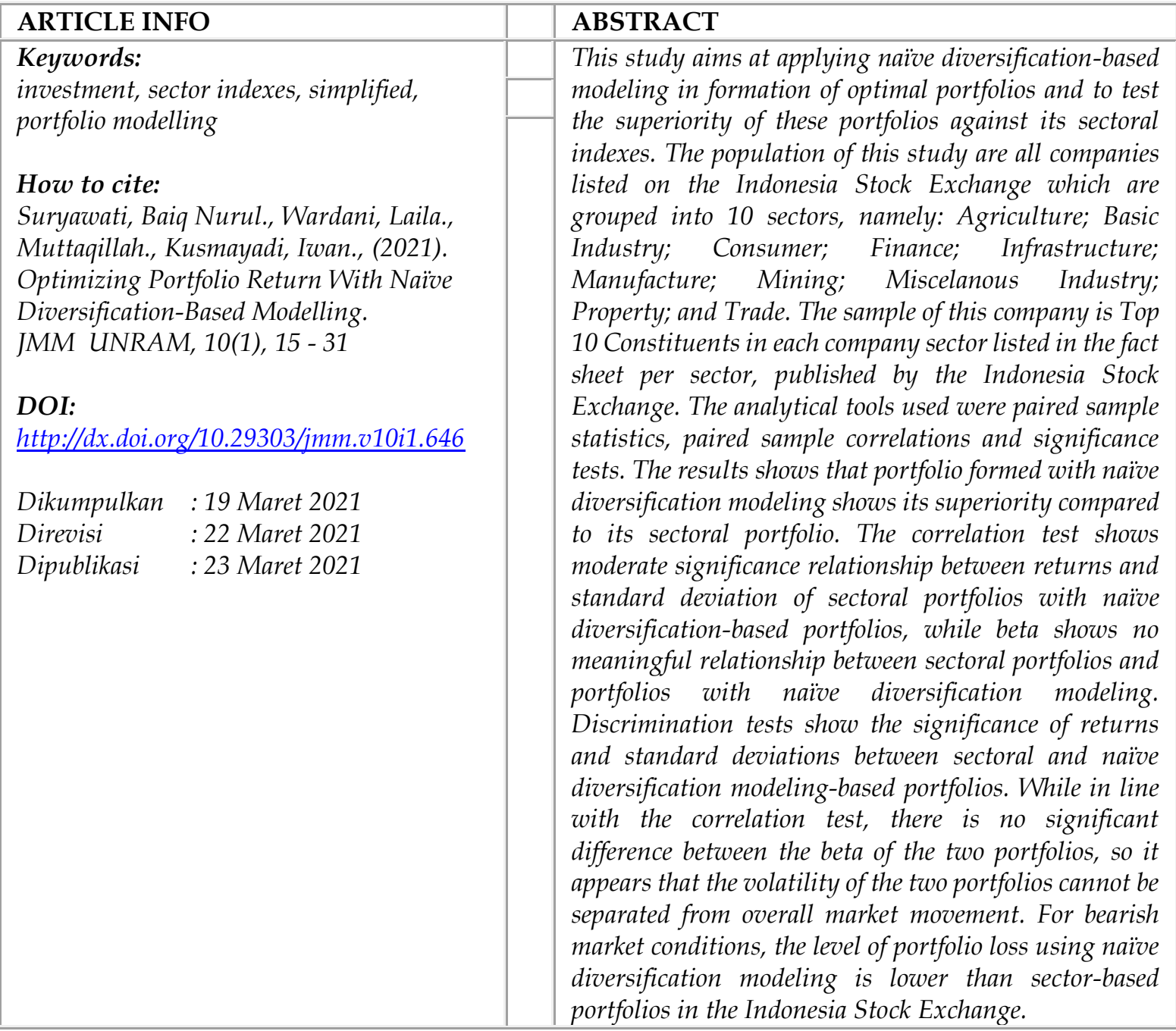




\section{INTRODUCTION}

The company becoming issuers in the capital market until this time are 676 according to the companies list in the Indonesia Stock Exchange website. Investment options are increasingly diverse, this creates opportunities for various stock combinations available to investors. Investors will not invest all their funds in one type of stock, they will diversify the shares in portfolios to reduce investment risk. To get optimum profit, ways to build a portfolio is one of the right tools. This effort is made to minimize risk or maximize return. The results of accuracy in forming a portfolio can be assessed to evaluate investment decision making that has been made. Return is the goal of investors in investing. For optimal returns there is a certain level of risk that must be taken. Investment risk comes from uncertainty in the future, there are two types of risk, namely systematic and unsystematic risk, systematic risk is usually influenced by market conditions and faced by all companies that go public, while unsystematic risk is usually caused by company policies and only happened to related companies.

There are two main things the investors consider when investing: rate of return and risk. Putri, Bramanti, \& Hakim's (2017) research shows that an investment advisor cannot use information of investors personality to predict level of investor risk tolerance. However, the information can be used to predict stock investment preferences that investors are willing to take. Investment advisors can use it to predict preferences for investment needs of stocks they are willing to take. As it is very difficult to predict investment needs, to study investor behavior the tendency of investors to get optimum return is used in mapping a pattern of their portfolio formation. Research by Umam, et al., (2017) shows that determining optimal portfolio using Single Index Model can provide optimal returns. Evidence of optimization is also shown by an indication that in a small sample, portfolios formed by Single Index Model Method and Naiive Diversification method have an inferior performance (Witiastuti, 2012). Research by Witiastuti (2012) shows contradictory results with the research of Umam, et al., (2017), so this research is designed in order that limitations of the research on investment options can be expanded by emphasizing more on various investment decisions available based on portfolio formation patterns with naive diversification.

Istiqlaliyah (2016) revealed that there are several factors commonly used in making investment decisions and adjusted for priority weights, namely: level of investment risk, investment profitability, product and competitive advantage, market attractiveness and technical ability. This is in line with Mudjiyono (2012) research which states that diversification or portfolios are carried out by carefully observing returns, this is done by conducting fundamental and technical analysis. Septyato, Sudarwan, \& Dewanto (2016) emphasize the existence of investor attitudes and behavior based on benefits of price information, where characteristics of quality financial information and price information are used in making decisions on assessing stock prospects. In addition, the dominant factor in decision making is fundamental knowledge rather than technical knowledge. Furthermore, if you look at the mechanism used to form a portfolio with Single Index Model or Naïve Diversification, price information is the main thing.

Hariasih \& Wirama (2016) explain that returns formed by Single Index method are outperformed compared to random method, but it is necessary to carry out continuous performance assessments both to return and risk aspect to produce an optimum portfolio. 
Lestari \& Iramani (2013) stated that investors who stated a risky condition would not have the tendency to take this action. Yoga \& Rikumahu (2018) have stated that portfolios formed with Naïve model are inferior to the portfolios with Markowitz model, but this study also emphasizes investor preferences in taking risks. Therefore, it can be examined carefully for different preferences, alternative investment choices may be varied. Single Index Model method only allows one portfolio to be taken because the portfolio is optimal portfolio.

The image below shows companies listed in the Indonesia Stock Exchange divided by constituent index and sectoral index. The constituent index represents interests of each constituent that makes up the index, while the division based on sectoral index is intended to divide companies into industrial sectors where they are involved in. The image excerpt is taken from weekly statistics published by the Indonesia Stock Exchange for the period of 17 21 February 2020. For sectoral index, it appears that Agriculture, Finance, and Trade $\mathcal{E}$ Service sectors show indications of negative decline on stock prices during the last week of February. For constituent index, it will be difficult to map which sector has decreased because the selection of stocks depends on preferences of index forming the institutions.

Figure 1. Weekly Statistic Period of 17 to 21 February 2020

\begin{tabular}{|c|c|c|c|c|c|c|c|c|c|}
\hline Index & $\mathrm{Hi}$ & Low & Close & Change & Index & $\mathrm{Hi}$ & Low & Close & Change \\
\hline Composite Index & $5,942.487$ & $5,867.523$ & $5,882.255$ & $0.26 \%$ & MNC36 & 337.028 & 332.945 & 333.929 & $0.16 \%$ \\
\hline LQ45 & 968.539 & 954.172 & 957.368 & $0.36 \%$ & Agriculture & $1,299.796$ & $1,274.685$ & $1,274.685$ & $(1.50 \%)$ \\
\hline IDX80 & 135.616 & 133.256 & 133.828 & $0.59 \%$ & Basic Industry & 884.689 & 859.155 & 860.734 & $0.51 \%$ \\
\hline Jakarta Islamic Index & 633.775 & 618.808 & 624.167 & $0.70 \%$ & Miscellanous Industry & $1,101.999$ & $1,075.455$ & $1,091.453$ & $1.42 \%$ \\
\hline Dev. Board Index & $1,033.324$ & $1,017.409$ & $1,033.324$ & $1.36 \%$ & Infrastructure & $1,021.452$ & $1,006.798$ & $1,021.452$ & $0.95 \%$ \\
\hline Kompas 100 & $1,210.228$ & $1,193.764$ & $1,196.330$ & $0.20 \%$ & Finance & $1,349.188$ & $1,335.244$ & $1,338.394$ & $(0.06 \%)$ \\
\hline BISNIS-27 & 537.995 & 530.756 & 532.770 & $0.34 \%$ & Trade \& Service & 704.848 & 695.178 & 695.178 & $(1.31 \%)$ \\
\hline PEFINDO25 & 306.799 & 301.005 & 301.005 & $(1.41 \%)$ & Manufacturing & $1,348.658$ & $1,320.261$ & $1,326.258$ & $0.50 \%$ \\
\hline SRI-KEHATI & 386.000 & 380.848 & 383.131 & $0.31 \%$ & IDX SMC Composite & 236.700 & 233.095 & 233.906 & $0.64 \%$ \\
\hline Pefindo i-Grade & 173.673 & 171.396 & 172.385 & $0.37 \%$ & IDX Value30 & 129.014 & 124.984 & 126.030 & $2.00 \%$ \\
\hline infobank15 & $1,035.890$ & $1,024.447$ & $1,027.900$ & $(0.04 \%)$ & IDX Growth 30 & 139.029 & 136.905 & 137.292 & $0.34 \%$ \\
\hline
\end{tabular}

Source: Indonesia Stock Exchange

This research is designed to confirm various investment options available based on industry sector as a return optimization test received by investors through portfolio formulation by using naïve diversification method. Therefore, the research questions are formulated as follows.

Research Questions:

1. How to form a portfolio by using naïve diversification method on the sectoral index?

2. Does the portfolio formed by using naïve diversification show superiority compared to the sectoral index performance?

\section{LITERATURE REVIEW}

\subsection{Types of Stock Price Indexes in the Indonesian Stock Exchange}

Stock price index is main indicator that describes stock price movements and is also one of leading indicators for the economy. In capital market an index is expected to have five functions: 
1. as an indicator of market trends,

2. as an indicator of profit level,

3. as a benchmark for a portfolio performance,

4. facilitating formation of a portfolio with passive strategy, and

5. facilitating development of derivative products.

In the Indonesia Stock Exchange, there are ten several indexes (IDX, 2010), including:

1. Individual index, using the price index of each stock toward its base price

2. Sectoral stock price index, using all stocks included in each sector. In the BEI, the sectoral index is divided into nine sectors, namely:

a. Primary (extractive) sectors: agriculture, mining.

b. Secondary sectors (manufacturing industry): basic and chemical industries, various industries, consumer goods industry.

c. Tertiary sectors (services): Property and real estate, transportation and infrastructures, financial, trade, services and investment.

3. LQ 45 Index, using 45 stocks selected based on stock trading liquidity and adjusted every six months (in the beginning of February and August), so that the stocks listed in the index will always change.

4. Jakarta Islamic Index (JII). This index is intended for Islamic stocks or stocks that have been declared halal by the National Sharia Council. Currently, it only consists of 30 halal shares and is adjusted every six months (in every beginning of January and July). Thus, the stocks contained in the index will always change.

5. The Composite Share Price Index (IHSG) uses all listed shares as a component of the index calculation.

6. Kompas 100 Index is 100 stocks selected based on liquidity factors, market capitalization and fundamental performance of the stocks. This index was launched on July 13, 2007 so that it can be used by investors, portfolio managers and fund managers as a reference in creating innovation (creativity) in stock-based fund management.

7. Business Index 27 is stock price index formed as a result of daily cooperation between Bisnis Indonesia and BEI. Bisnis Indonesia here is an independent party expected to be able to manage the index more independently and flexibly. Selection of index constituents is based on the issuers performance with the criteria of fundamental selection, historical data transaction (technical) and accountability. This index was only introduced to the public on January 27, 2009.

8. Pefindo Index 25 is an index intended to provide additional investment guidelines for investors by creating new benchmark index that specifically perform Small and Medium Enterprises (SME) through consistent criteria and methodologies. This new index was launched on 18 May 2009.

9. Sri-Kehati Index is an index created to provide additional investment guidelines for investors who prefer issuers that have excellent performance on encouraging sustainable businesses as well as awareness of environment, social and good corporate governance. The index is under a collaboration between PT. BEI, Indonesian Biodiversity Foundation (Yayasan Kehati) and SRI which stands for Social and Responsible Investment. This index was launched on June 8, 2009 with a total of 25 shares. Main Board and Development Board Index is the indexes that show a collection of stocks listed on the main and development board. The Main Board is intended for issuers that have large size and have good track record. In another hand, the Development Board is intended for companies that have not been able to meet requirements for being listed on the main board, including 
companies that have good prospects but have not yet made a profit as well as a mean for companies that are currently participating. This index was launched on April 8, 2002.

10.The SMInfra Index 18 is an index consisting of 18 stocks whose constituents are selected from main infrastructure sectors or several supporting sectors in infrastructure development. This index refers to the hypothesis of "infrastructure development" that will play an important role in Indonesia future economic development. Government will focus more on infrastructure development, so that infrastructure becomes a prospective and attractive sector for investors. Capital market investors (investment managers, pension funds, insurance and individual investors) need a more specific reference to infrastructure stocks as an investment reference.

The index basically uses the same calculation method, what distinguishes it is number of shares used as a component in the calculation. The four indexes are displayed continuously through a display wall on the trading floor and disseminated to vendor data through the data feed.

\subsection{Risk and Return}

In the uncertainty world, it is very difficult for investors to ascertain the exact amount of cash flows expected to be received in the future. One of the approaches taken is to calculate the expected cash flow. The expected cash flows are weighted with average cash flows that may be generated. Talking about return rate, it certainly cannot be separated from the risk. This is because level of return and risk are two inseparable things and it is also because consideration of an investment is a trade-off or exchange of the two factors.

Risk is often associated with deviation from outcomes received with outcomes expected. Van Horne (1997) said "risk is the variability of returns from those that are expected" Therefore, there are two dimensions of risk, either deviating smaller or deviating larger. Risk is variability of return on the expected return. Risk is manifested in a form of standard deviation which measures absolute value of the deviation of values that have occurred with the average value (as an expected value). Tandelilin (2010) explains that to visualizing risk, a symbol is used called standard deviation. Standard deviation is used as risk measure of realization return. Then to measure risk of expected returns, it is used variance. Variance is nothing but square of standard deviation. There are three possible identified attitudes in dealing with risks (Jogiyanto, 2009):

1. A risk seeker is investors will choose an investment that has a higher risk for the same expected rate of return.

2. Risk averter is investors will choose an investment that has a lower risk for the same expected rate of return.

3. Risk neutral is a moderate group, positioned between the two groups. This group will choose an investment with a return that is in accordance with the risks faced.

Business managers and shareholders are generally categorized into risk averters, people who do not like risk or prefer high average returns and low return variants.

\subsection{Passive and Active Strategy in Investment}

\subsubsection{Passive Strategy}

This strategy is a result of investors trust over efficient markets, so they believe that stock price is the best estimate stock value. According to Tandelilin (2001), passive strategy generally consists of two types of strategies, namely buy and hold strategy and index fun. In carrying out passive strategy, an investor simply selects certain stocks with returns and risks adjusted for their consideration. For buy and hold strategy, they only buy once then hold it 
for a long time. Besides that passive investment strategy can also effectively be applied to index funds. Index funds show investments made based on a composite index within a country. The process is carried out with several assumptions, such as market is very efficient, investments are carried out at an efficient cost, investments are carried out actively and investments made bring tax advantages.

\subsubsection{Active Strategy}

Investors who choose active strategy have opposite idea with investors who take passive strategy. In passive strategy, an investor is very active to collect information and take various speculative actions to get an abnormal return. The better an investors ability to find fast and precise information and speculate whether to sell or buy new shares, the more it will certainly affect the investment returns that will be obtained. An investor who develops Active Strategy tends to do short-term speculation. One of the most well-known Active Strategies is momentum, a method where the market or investor shall be smart in buying stocks that are categorized as winners and selling stocks that are categorized as loser. A speculation of buying stocks that are in winner positions is by assuming that momentum will continue to encourage an increase in the stock market value.

\subsection{Portfolio Model of Nä̈ve Diversification}

Naive or random portfolios are carried out by investors by randomly investing their funds in different types of stocks or in different types of assets and hoping that variance of return as portfolio risk measure will be reduced. The more securities added randomly to the portfolio, the less unsystematic risk an investor will face. Naïve or random diversification is simple diversification which can be defined as "don't put all your eggs in one basket" or "spread the risk". Naïve or random diversification is a decision to diversify securities randomly. Simply, an investor chooses a large number of securities randomly (Jones, 1996). Therefore, according to this method, a portfolio consisting of 200 different stocks will be diversified 10 times compared to a portfolio consisting of only 20 different stocks.

\section{RESEARCH METHOD}

\subsection{Population and Research Sample}

Population in this study were stocks that were active in the Indonesia Stock Exchange until $1^{\text {st }}$ semester of 2020 . The sample was taken by using purposive sampling method. The sample is stocks that are included in the sectoral index. Secondary data on stock sample prices are obtained from daily prices published by the Indonesia Stock Exchange, accessed through the yahoo finance website.

\subsection{Research Terms Definition}

1. A portfolio is an optimal combination of shares owned, in a sense that it can produce the same level of profit with a lower risk, or with the same risk it can provide a higher level of return.

2. Naïve or random diversification is simple diversification which can be defined as "don't put all your eggs in one basket" or "spread the risk". Naïve or random diversification is a decision to diversify securities randomly by selecting simple or traditional stocks per sectoral index.

\subsection{Technique of Data Analysis}

Yoga \& Rikumahu (2018) apply a series of stages to form an optimal portfolio based on naïve diversification as follows: 
a. Calculating profit rate of each stock in the sectoral index

b. Calculating expected return of each stock in the sectoral index

c. Calculating investment risk of each stock in the sectoral index by calculating variance and standard deviation

d. Calculating covariance

e. Calculating correlation coefficient

f. Calculating expected return of the portfolio

g. Calculating portfolio risk

h. Calculating distribution of weight of the Naïve portfolio

\section{RESULTS AND DISCUSSION}

\subsection{Research Results}

4.1.1. Data Description

Based on the fact sheet published by the Indonesia Stock Exchange, comparison of returns, standard deviation and beta of ten (10) business grouping sectors from 2009 to 2019, it can be summarized in the following table:

Table 1. Comparison of Return, Standard Deviation and Beta Based on Company Sector in Indonesian Stock Exchange, 20092019

\begin{tabular}{|c|l|r|r|c|}
\hline No & \multicolumn{1}{|c|}{ Sektor } & \multicolumn{1}{c|}{ Return } & \multicolumn{1}{c|}{ StDev } & \multicolumn{1}{c|}{ Beta } \\
\hline $\mathbf{1}$ & AGRI & $\mathbf{- 0 . 1 8 2}$ & 0.037 & $\mathbf{0 . 4 6 0}$ \\
\hline $\mathbf{2}$ & BASIC-IND & $\mathbf{0 . 8 1 7}$ & 0.044 & $\mathbf{1 . 1 6 0}$ \\
\hline $\mathbf{3}$ & CONSUMER & -0.117 & 0.038 & 1.070 \\
\hline $\mathbf{4}$ & FINANCE & 0.669 & 0.034 & 1.060 \\
\hline $\mathbf{5}$ & INFRASTRUCTURE & 0.078 & 0.040 & 1.110 \\
\hline $\mathbf{6}$ & MANUFACTURE & 0.067 & 0.033 & 1.110 \\
\hline $\mathbf{7}$ & MINING & 0.118 & 0.043 & 0.860 \\
\hline $\mathbf{8}$ & MISC-IND & -0.107 & $\mathbf{0 . 0 4 9}$ & 1.110 \\
\hline $\mathbf{9}$ & PROPERTY & -0.027 & 0.034 & 0.870 \\
\hline $\mathbf{1 0}$ & TRADE & -0.106 & $\mathbf{0 . 0 2 4}$ & 0.590 \\
\hline
\end{tabular}

The above data is compilation of fact sheets per sector from 2009 to 2019. From the data above, it can be seen the return, standard deviation and beta of each sector for 10 years. The business sector on the Indonesia Stock Exchange is divided into ten (10) main groups, namely: Agriculture; Basic Industry; Consumer; Finance; Infrastructure; Manufacture; Mining; Miscellaneous Industry; Property; and Trade. Return data shows returns obtained from investment in the last 10 years, Basic Industry shows its superiority among other sectors. Based on table 1, it can be seen that beta is a measure of volatility which takes into account the range of the highest and lowest returns and the effect of market returns on individual returns. The data show the same pattern as returns where expression of high-risk high return applies, where high returns in basic industry sector show a high beta too. Minimum return shown by the agriculture sector also shows a low beta. To clarify the comparisons between sectors, you can see the comparison chart of returns, standard deviation and beta, per sector, for the period of 2009 to 2019 below: 
Graph 1. Comparison of Return, Standard Deviation and Beta Companies based on its Sector, in Indonesian Stock Exchange, 2009 - 2019

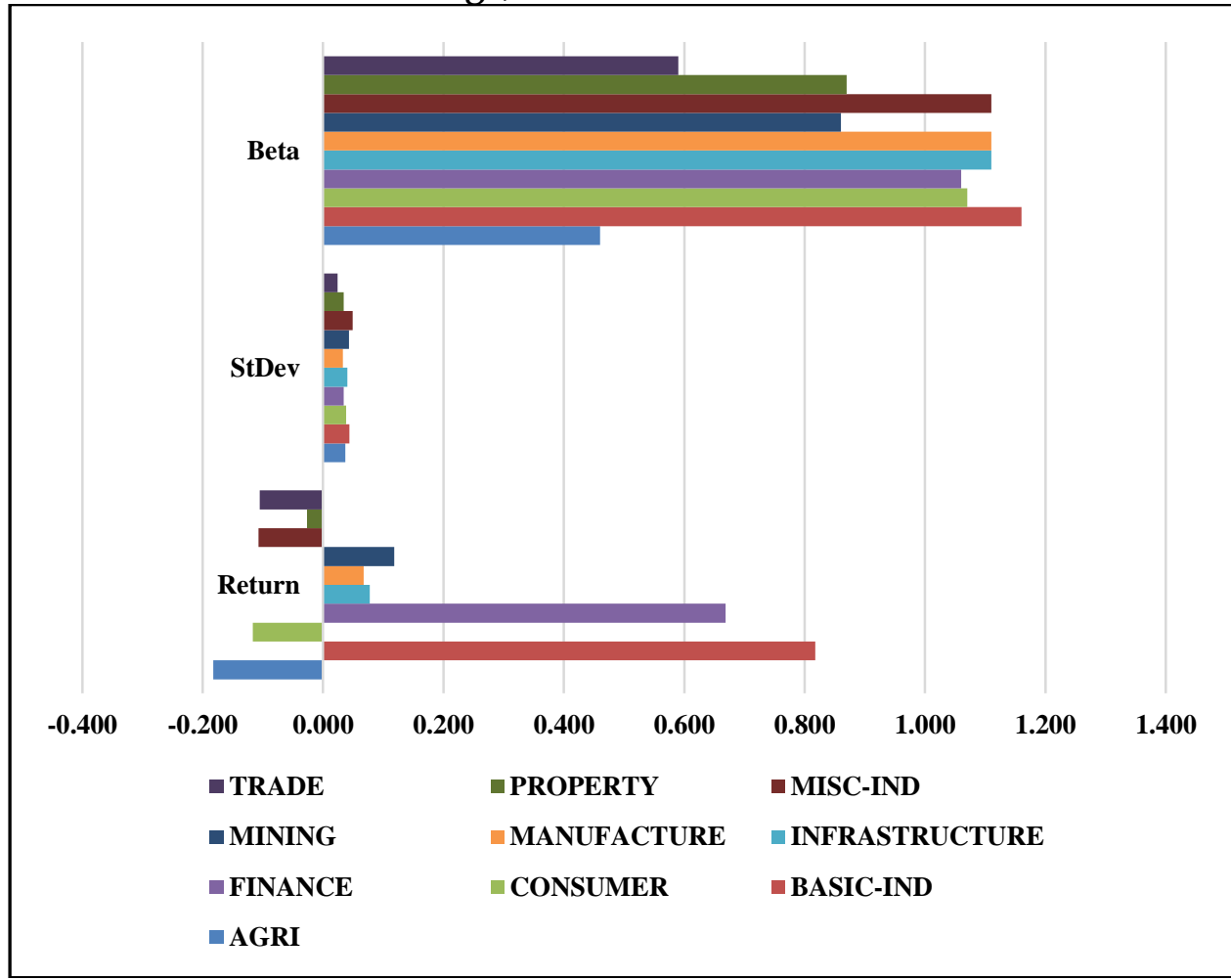

The graph above shows basic industry and finance sectors are the sectors that give the highest returns. To get a description of sectoral returns, the following table ranks sectors that provide the highest to the lowest returns.

Table 2. Rank of Return, StDev, and Beta Companies based on its Sector in Indonesian Stock Exchange, 2009-2019

\begin{tabular}{|c|c|c|c|c|}
\hline No & Sektor & Return & StDev & Beta \\
\hline 1 & BASIC-IND & 0.817 & 0.044 & 1.160 \\
\hline 2 & FINANCE & 0.669 & 0.034 & 1.060 \\
\hline 3 & MINING & 0.118 & 0.043 & 0.860 \\
\hline 4 & INFRASTRUCTURE & 0.078 & 0.040 & 1.110 \\
\hline 5 & MANUFACTURE & 0.067 & 0.033 & 1.110 \\
\hline 6 & PROPERTY & -0.027 & 0.034 & 0.870 \\
\hline 7 & TRADE & -0.106 & 0.024 & 0.590 \\
\hline 8 & MISC-IND & -0.107 & 0.049 & 1.110 \\
\hline 9 & CONSUMER & -0.117 & 0.038 & 1.070 \\
\hline 10 & AGRI & -0.182 & 0.037 & 0.460 \\
\hline
\end{tabular}

Based on the ranking table above, it can be seen that five (5) main sectors that gave the highest returns during 2009 to 2019 are basic industry; finance; mining; infrastructure; and manufacture. Meanwhile 5 other sectors that gave negative returns are property sector; trade; miscellaneous industry; consumer and agriculture. From the data above, it can also be seen that mining sector returns are shown to be higher than infrastructure and manufacture sectors, but beta of these sectors is higher than other sectors. In contrast to beta which shows the influence of market risk on individual risk, standard deviation of mining sector is 0.43 which is actually higher than other sectors with lower returns. This indication shows that 
miscellaneous industry sector shows high standard deviation and beta. This shows that miscellaneous industry sector has been unfavorable in the last 10 years, especially if the return given is negative. It means that there is a capital loss or a decrease in the value of companies in miscellaneous industry sector.

\subsubsection{Analysis of Portfolio Formulation with Nä̈ve Diversification Modelling}

Naïve diversification is carried out by dividing proportion of portfolio into 10 main companies that have been described in the data description. Following is presented in tabulation of results of portfolio formation with naïve diversification modelling:

1. Calculating profit rate of each stock and expected return of each share on agriculture sectoral index.

\begin{tabular}{|c|c|c|c|c|c|c|c|c|}
\hline $\begin{array}{c}\mathbf{N} \\
\mathbf{o}\end{array}$ & Kode & Januari 2020 & $\begin{array}{c}\text { Pebruari } \\
\mathbf{2 0 2 0}\end{array}$ & Maret 2020 & April 2020 & Mei 2020 & Juni 2020 & $\begin{array}{c}\text { Expected } \\
\text { Return }\end{array}$ \\
\hline 1 & AALI & -0.042615989 & -0.057205591 & -0.094366868 & -0.010124786 & 0.054246926 & -0.02302 & -0.028848353 \\
\hline 2 & ANTJ & -0.00571441 & -0.056995312 & -0.061872955 & -0.009584267 & -0.045406082 & 0.06087 & -0.019783872 \\
\hline 3 & BWPT & -0.105849048 & -0.118581263 & -0.038356906 & -0.017465832 & 0.000172401 & 0.024598 & -0.042580427 \\
\hline 4 & DSNG & -0.060119205 & -0.037766542 & -0.044393087 & 0.000267168 & -0.008386077 & 0.024756 & -0.020940369 \\
\hline 5 & LSIP & -0.063047484 & -0.086202475 & -0.011099327 & -0.047574553 & -0.018569351 & 0.026444 & -0.033341583 \\
\hline 6 & MGRO & -0.003232523 & -0.03247133 & -0.032045973 & 0.022983302 & 0.000328774 & -0.0124 & -0.009473003 \\
\hline 7 & SGRO & 0.000984317 & -0.02551596 & 0.007672722 & 0.001354839 & -0.021413655 & -0.02536 & -0.010379429 \\
\hline 8 & SIMP & -0.053407388 & -0.0965311 & -0.051166337 & -0.026395173 & -0.019020517 & 0.04019 & -0.034388467 \\
\hline 9 & SMAR & -0.01588937 & -0.037706898 & -0.098981569 & 0.031016831 & -0.017071474 & 0.011622 & -0.021168452 \\
\hline 10 & SSMS & -0.006160216 & 0.004205975 & 0.052029 & -0.035666331 & -0.02113758 & -0.02088 & -0.004600721 \\
\hline
\end{tabular}

2. Calculating investment risk by calculating variance, standard deviation of covariance and correlation coefficient.

\begin{tabular}{|c|c|r|r|r|r|}
\hline No & Kode & Variance Saham & \multicolumn{1}{|c|}{ Standar Deviasi } & \multicolumn{1}{c|}{ Covariance } & \multicolumn{1}{c|}{ Koefisien Korelasi } \\
\hline 1 & AALI & 0.002515136 & 0.05015113 & 0.00077959 & 0.910807217 \\
\hline 2 & ANTJ & 0.002123935 & 0.046086169 & 0.0003943 & 0.501305341 \\
\hline 3 & BWPT & 0.003353677 & 0.057910938 & 0.00067244 & 0.68035792 \\
\hline 4 & DSNG & 0.001012723 & 0.031823312 & 0.00040523 & 0.746098203 \\
\hline 5 & LSIP & 0.001633302 & 0.040414125 & 0.00024892 & 0.360887056 \\
\hline 6 & MGRO & 0.000447092 & 0.021144555 & 0.00028963 & 0.802568762 \\
\hline 7 & SGRO & 0.000233592 & 0.015283712 & $-8.461 \mathrm{E}-05$ & -0.32435326 \\
\hline 8 & SIMP & 0.002073379 & 0.045534371 & 0.00053623 & 0.690007456 \\
\hline 9 & SMAR & 0.002034312 & 0.045103343 & 0.00062389 & 0.810484159 \\
\hline 10 & SSMS & 0.000958063 & 0.030952586 & -0.0004624 & -0.875382499 \\
\hline
\end{tabular}

3. Calculating return, risk and beta of the portfolio by dividing portfolio weight of naïve diversification, $1 / \mathrm{n}$ or $1 / 10$, based on the ranking of ten companies that provide main contribution per index carried out by the Indonesia Stock Exchange. Following is the table of calculation result for agriculture sector. 
Table 3. Comparison of Return, Risk and Beta Portfolio formed with naïve diversification for the 1st semester 2020 period in the agriculture sector

\begin{tabular}{|c|c|r|r|r|}
\hline No & Kode & Return Portofolio & Risiko Portofolio & Beta Portofolio \\
\hline 1 & AALI & -0.0028848353 & 0.0000428655 & 0.2230329049 \\
\hline 2 & ANTJ & -0.0019783872 & 0.0001590175 & 0.1128066489 \\
\hline 3 & BWPT & -0.0042580427 & 0.0001801304 & 0.1923799452 \\
\hline 4 & DSNG & -0.0020940369 & 0.0000448978 & 0.1159319474 \\
\hline 5 & LSIP & -0.0033341583 & 0.0001420581 & 0.0712141419 \\
\hline 6 & MGRO & -0.0009473003 & 0.0000159113 & 0.0828595478 \\
\hline 7 & SGRO & -0.0010379429 & 0.0000209017 & -0.0242052102 \\
\hline 8 & SIMP & -0.0034388467 & 0.0001086222 & 0.1534104262 \\
\hline 9 & SMAR & -0.0021168452 & 0.0000698004 & 0.1784904626 \\
\hline 10 & SSMS & -0.0004600721 & 0.0000223904 & -0.1322989982 \\
\hline & & $-\mathbf{0 . 0 2 2 5 5 0 4 6 7 6}$ & $\mathbf{0 . 0 0 0 8 0 6 5 9 5 3}$ & $\mathbf{0 . 9 7 3 6 2 1 8 1 6 6}$ \\
\hline
\end{tabular}

Table 4. Comparison of Return, Risk and Beta Portfolio with Naïve diversification modeling for basic-ind sector companies, semester 1, 2020

\begin{tabular}{|c|l|r|r|r|}
\hline No & Kode & Return Portofolio & Risiko Portofolio & Beta Portofolio \\
\hline $\mathbf{1}$ & BRPT & 0.002757439 & 0.000575357 & 0.136884057 \\
\hline $\mathbf{2}$ & CPIN & 0.000441478 & 0.000070803 & 0.239212199 \\
\hline $\mathbf{3}$ & FASW & 0.000198321 & 0.000016179 & 0.019163288 \\
\hline $\mathbf{4}$ & INKP & -0.001474498 & 0.000054514 & 0.196029551 \\
\hline $\mathbf{5}$ & INTP & -0.001425581 & 0.000030369 & 0.145131545 \\
\hline $\mathbf{6}$ & JPFA & -0.002180026 & 0.000041619 & 0.130646791 \\
\hline $\mathbf{7}$ & SMCB & 0.000308916 & 0.000457688 & 0.220295220 \\
\hline $\mathbf{8}$ & SMGR & -0.000228751 & 0.000069711 & 0.257522207 \\
\hline $\mathbf{9}$ & TKIM & -0.004467497 & 0.000218632 & 0.209051473 \\
\hline $\mathbf{1 0}$ & TPIA & 0.000154317 & 0.000113230 & 0.062124926 \\
\hline & & -0.005915881 & 0.001648103 & 1.616061257 \\
\hline
\end{tabular}

Table 5. Comparison of Return, Risk and Beta Portfolio with Naïve diversification modeling for consumer companies sector, semester 1, 2020

\begin{tabular}{|c|c|r|r|r|}
\hline No & Kode & Return Portofolio & Risiko Portofolio & Beta Portofolio \\
\hline $\mathbf{1}$ & GGRM & -0.00075115 & 0.00003035 & 0.07374940 \\
\hline $\mathbf{2}$ & HMSP & -0.00081049 & 0.00007912 & 0.13229159 \\
\hline $\mathbf{3}$ & ICBP & -0.00154755 & 0.00006660 & 0.00759185 \\
\hline $\mathbf{4}$ & INDF & -0.00165482 & 0.00009019 & 0.03869756 \\
\hline $\mathbf{5}$ & KLBF & 0.00037379 & 0.00016811 & 0.13142254 \\
\hline $\mathbf{6}$ & MLBI & -0.00153217 & 0.00004215 & 0.09851753 \\
\hline $\mathbf{7}$ & MYOR & -0.00009973 & 0.00004176 & 0.07398396 \\
\hline $\mathbf{8}$ & SIDO & 0.00005016 & 0.00002152 & -0.01091141 \\
\hline $\mathbf{9}$ & ULTJ & 0.00042736 & 0.00001129 & 0.03479469 \\
\hline $\mathbf{1 0}$ & UNVR & -0.00058415 & 0.00006492 & 0.08026886 \\
\hline & & $-\mathbf{0 . 0 0 6 1 2 8 7 3}$ & $\mathbf{0 . 0 0 0 6 1 6 0 2}$ & $\mathbf{0 . 6 6 0 4 0 6 5 7}$ \\
\hline
\end{tabular}


Table 7. Comparison of Return, Risk and Beta Portfolio with Naïve diversification modeling for finance companies sector, semester 1, 2020

\begin{tabular}{|c|c|r|r|r|}
\hline No & Kode & Return Portofolio & Risiko Portofolio & Beta Portofolio \\
\hline $\mathbf{1}$ & BBCA & -0.0011774 & 0.0000074 & 0.0427225 \\
\hline $\mathbf{2}$ & BBNI & -0.0015113 & 0.0000523 & 0.1628690 \\
\hline $\mathbf{3}$ & BBRI & -0.0007804 & 0.0000510 & 0.1608087 \\
\hline $\mathbf{4}$ & BDMN & -0.0016432 & 0.0000731 & 0.1930329 \\
\hline $\mathbf{5}$ & BMRI & -0.0013585 & 0.0000381 & 0.1348031 \\
\hline $\mathbf{6}$ & BNLI & -0.0006762 & 0.0000199 & 0.1264811 \\
\hline $\mathbf{7}$ & BTPS & -0.0039753 & 0.0004323 & 0.3044303 \\
\hline $\mathbf{8}$ & MAYA & -0.0011410 & 0.0000785 & 0.1519665 \\
\hline $\mathbf{9}$ & MEGA & 0.0020911 & 0.0000290 & -0.0729421 \\
\hline $\mathbf{1 0}$ & SMMA & 0.0003867 & 0.0000746 & 0.1052242 \\
\hline & & $-\mathbf{0 . 0 0 9 7 8 5 5}$ & $\mathbf{0 . 0 0 0 8 5 6 0}$ & $\mathbf{1 . 3 0 9 3 9 6 1}$ \\
\hline
\end{tabular}

Table 8. Comparison of Return, Risk and Beta Portfolio with Naïve diversification modeling for infrastructure companies sector, semester 1, 2020

\begin{tabular}{|r|c|r|r|r|}
\hline No & Kode & Return Portofolio & Risiko Portofolio & Beta Portofolio \\
\hline 1 & EXCL & 0.000263250 & 0.000070258 & 0.132515720 \\
\hline 2 & FREN & -0.001827391 & 0.000133619 & 0.131723681 \\
\hline 3 & ISAT & -0.001193050 & 0.000123344 & 0.097344595 \\
\hline 4 & JSMR & -0.001377563 & 0.000118290 & 0.209158636 \\
\hline 5 & PGAS & -0.002911338 & 0.000023826 & 0.246156518 \\
\hline 6 & POWR & -0.002229577 & 0.000034699 & 0.144481244 \\
\hline 7 & TBIG & -0.000215173 & 0.000126800 & 0.124131630 \\
\hline 8 & TCPI & -0.001517218 & 0.000071203 & 0.076221330 \\
\hline 9 & TLKM & -0.000763218 & 0.000031505 & 0.097700327 \\
\hline 10 & TOWR & 0.001244626 & 0.000090186 & 0.204238026 \\
\hline & & $\mathbf{- 0 . 0 1 0 5 2 6 6 5 2}$ & $\mathbf{0 . 0 0 0 8 2 3 7 3 0}$ & $\mathbf{1 . 4 6 3 6 7 1 7 0 9}$ \\
\hline
\end{tabular}

Table 9. Comparison of Return, Risk and Beta Portfolio with Naïve diversification modeling for manufacturing companies sector, semester 1, 2020

\begin{tabular}{|r|c|r|r|r|}
\hline No & Kode & Return Portofolio & Risiko Portofolio & Beta Portofolio \\
\hline 1 & AASI & -0.0013505 & 0.0000939 & 0.2363856 \\
\hline 2 & BRPT & 0.0027574 & 0.0005754 & 0.1368841 \\
\hline 3 & CPIN & 0.0004415 & 0.0000708 & 0.2392122 \\
\hline 4 & GGRM & -0.0007511 & 0.0000304 & 0.0737494 \\
\hline 5 & HMSP & -0.0008105 & 0.0000791 & 0.1322916 \\
\hline 6 & ICBP & -0.0015475 & 0.0000666 & 0.0075918 \\
\hline 7 & KLBF & 0.0003738 & 0.0001681 & 0.1314225 \\
\hline 8 & SMGR & -0.0002287 & 0.0000697 & 0.2575222 \\
\hline 9 & TPIA & -0.0005558 & 0.0001048 & 0.0827647 \\
\hline 10 & UNVR & -0.0005841 & 0.0000649 & 0.0802689 \\
\hline & & $-\mathbf{0 . 0 0 2 2 5 5 7}$ & $\mathbf{0 . 0 0 1 3 2 3 7}$ & $\mathbf{1 . 3 7 8 0 9 3 0}$ \\
\hline
\end{tabular}


Table 10. Comparison of Return, Risk and Beta Portfolio with Naïve diversification modeling for mining companies sector, semester 1, 2020

\begin{tabular}{|r|l|r|r|r|}
\hline No & Kode & Return Portofolio & Risiko Portofolio & Beta Portofolio \\
\hline 1 & ADRO & -0.00186549 & 0.00013836 & 0.04112272 \\
\hline 2 & ANTM & -0.00312070 & 0.00003232 & 0.14829334 \\
\hline 3 & BYAN & -0.00020245 & 0.00000537 & 0.02433717 \\
\hline 4 & DSSA & 0.00306894 & 0.00010226 & -0.11744631 \\
\hline 5 & INCO & -0.00198072 & 0.00018110 & 0.08400426 \\
\hline 6 & ITMG & -0.00218565 & 0.00013186 & 0.03011325 \\
\hline 7 & MDKA & 0.00034715 & 0.00004315 & 0.05586647 \\
\hline 8 & MEDC & -0.00413742 & 0.00003737 & 0.04538301 \\
\hline 9 & PTBA & -0.00213952 & 0.00007926 & 0.04942102 \\
\hline 10 & GEMS & 0.00000000 & 0.00000000 & 0.00000000 \\
\hline & & $-\mathbf{0 . 0 1 2 2 1 5 8 5 7}$ & $\mathbf{0 . 0 0 0 7 5 1 0 4 3}$ & $\mathbf{0 . 3 6 1 0 9 4 9 1 6}$ \\
\hline
\end{tabular}

Table 11. Comparison of Return, Risk and Beta Portfolio with Naïve diversification modeling for misc-ind companies sector, semester 1, 2020

\begin{tabular}{|r|c|r|r|r|}
\hline No & Kode & Return Portofolio & Risiko Portofolio & Beta Portofolio \\
\hline 1 & ARKA & -0.00651407 & 0.00106024 & -0.05592954 \\
\hline 2 & ASII & -0.00135053 & 0.00009389 & 0.23638559 \\
\hline 3 & AUTO & -0.00190557 & 0.00001136 & 0.11210538 \\
\hline 4 & BRAM & -0.00003860 & 0.00016183 & 0.19760887 \\
\hline 5 & GMFI & -0.00448809 & 0.00020377 & 0.12204036 \\
\hline 6 & MASA & -0.00007766 & 0.00017144 & 0.01157721 \\
\hline 7 & SLIS & 0.00105534 & 0.00002889 & 0.02257773 \\
\hline 8 & SMSM & -0.00096653 & 0.00006319 & 0.03212609 \\
\hline 9 & SRIL & -0.00243719 & 0.00006606 & 0.08254349 \\
\hline 10 & UCID & -0.00043368 & 0.00024631 & 0.19339948 \\
\hline & & $-\mathbf{0 . 0 1 7 1 5 6 5 6}$ & $\mathbf{0 . 0 0 2 1 0 6 9 7 8}$ & $\mathbf{0 . 9 5 4 4 3 4 6 6}$ \\
\hline
\end{tabular}

Table 12. Comparison of Return, Risk and Beta Portfolio with Naïve diversification modeling for property companies sector, semester 1, 2020

\begin{tabular}{|r|c|r|r|r|}
\hline No & Kode & Return Portofolio & Risiko Portofolio & Beta Portofolio \\
\hline 1 & BSDE & -0.00427155 & 0.00002576 & 0.08663446 \\
\hline 2 & CTRA & -0.00366526 & 0.00028397 & 0.18807807 \\
\hline 3 & LPKR & -0.00025265 & 0.00014252 & 0.28433924 \\
\hline 4 & MKPI & -0.00007152 & 0.00000003 & 0.00343188 \\
\hline 5 & MPRO & -0.00217924 & 0.00047337 & 0.14510323 \\
\hline 6 & POLL & -0.00376318 & 0.00059482 & -0.05139652 \\
\hline 7 & PWON & -0.00242293 & 0.00007200 & 0.10297928 \\
\hline 8 & SMRA & -0.00349735 & 0.00014418 & 0.21654506 \\
\hline 9 & WIKA & -0.00316689 & 0.00016964 & 0.22362147 \\
\hline 10 & WSKT & -0.00412360 & 0.00002479 & 0.23962035 \\
\hline & & $-\mathbf{0 . 0 2 7 4 1 4 1 7 7}$ & $\mathbf{0 . 0 0 1 9 3 1 0 7 9}$ & $\mathbf{1 . 4 3 8 9 5 6 5 2 7}$ \\
\hline
\end{tabular}


Table 13. Comparison of Return, Risk and Beta Portfolio with Naïve diversification modeling for trade companies sector, semester 1, 2020

\begin{tabular}{|r|c|r|r|r|}
\hline No & Kode & Return Portofolio & Risiko Portofolio & Beta Portofolio \\
\hline 1 & ACES & 0.00206505 & 0.00010753 & 0.16914881 \\
\hline 2 & AMRT & -0.00009551 & 0.00003907 & 0.02866813 \\
\hline 3 & DNET & 0.00111863 & 0.00001157 & -0.04696325 \\
\hline 4 & EMTK & 0.00085684 & 0.00005130 & 0.09153762 \\
\hline 5 & IPTV & -0.00124464 & 0.00001822 & -0.01355102 \\
\hline 6 & MAPI & -0.00262132 & 0.00009535 & 0.28337903 \\
\hline 7 & MIKA & 0.00049321 & 0.00003432 & 0.12578516 \\
\hline 8 & MNCN & -0.00330276 & 0.00008218 & 0.07523510 \\
\hline 9 & SCMA & 0.00029928 & 0.00003328 & 0.30479273 \\
\hline 10 & UNTR & -0.00144654 & 0.00005278 & 0.04665583 \\
\hline & & $-\mathbf{0 . 0 0 3 8 7 7 7 5}$ & $\mathbf{0 . 0 0 0 5 2 5 5 9}$ & $\mathbf{1 . 0 6 4 6 8 8 1 3}$ \\
\hline
\end{tabular}

Following table is a description of returns comparison, standard deviation and beta portfolios formed with naïve diversification modeling and index per sector.

Table 14. Comparison of returns, standard deviation and portfolio beta per sector and those formed with naïve diversification modeling.

\begin{tabular}{|c|l|r|r|r|r|r|r|}
\hline $\begin{array}{l}\mathbf{N} \\
\mathbf{0}\end{array}$ & \multicolumn{1}{|c|}{ Sektor } & $\begin{array}{l}\text { Return } \\
\text { Sektoral }\end{array}$ & $\begin{array}{l}\text { Return } \\
\text { Naïve }\end{array}$ & $\begin{array}{l}\text { StDev } \\
\text { Sektoral }\end{array}$ & $\begin{array}{l}\text { StDev } \\
\text { Naïve }\end{array}$ & $\begin{array}{l}\text { Beta } \\
\text { Sektoral }\end{array}$ & \multicolumn{1}{l}{$\begin{array}{l}\text { Beta } \\
\text { Naïve }\end{array}$} \\
\hline $\mathbf{1}$ & AGRI & -0.133 & -0.023 & 0.034 & 0.001 & 1.596 & 0.974 \\
\hline $\mathbf{2}$ & BASIC-IND & -0.109 & -0.006 & 0.045 & 0.002 & 2.040 & 1.616 \\
\hline $\mathbf{3}$ & CONSUMER & -0.069 & -0.006 & 0.022 & 0.001 & 0.952 & 0.660 \\
\hline $\mathbf{4}$ & FINANCE & -0.080 & -0.010 & 0.025 & 0.001 & 1.087 & 1.309 \\
\hline $\mathbf{5}$ & $\begin{array}{l}\text { INFRASTRUC } \\
\text { TURE }\end{array}$ & -0.091 & -0.011 & 0.033 & 0.001 & 1.424 & 1.464 \\
\hline $\mathbf{6}$ & $\begin{array}{l}\text { MANUFACTU } \\
\text { RE }\end{array}$ & -0.087 & -0.002 & 0.031 & 0.001 & 1.457 & 1.378 \\
\hline $\mathbf{7}$ & MINING & -0.100 & -0.012 & 0.013 & 0.001 & 0.587 & 0.361 \\
\hline $\mathbf{8}$ & MISC-IND & -0.090 & -0.017 & 0.049 & 0.002 & 2.185 & 0.954 \\
\hline $\mathbf{9}$ & PROPERTY & -0.132 & -0.027 & 0.026 & 0.002 & 0.996 & 1.439 \\
\hline $\mathbf{1 0}$ & TRADE & -0.074 & -0.004 & 0.019 & 0.001 & 0.899 & 1.065 \\
\hline
\end{tabular}

Besides being presented in tabulation, the following graph describes comparison of returns, standard deviations, and beta portfolio formed with naïve diversification and indexes per sector in the Indonesia Stock Exchange. 


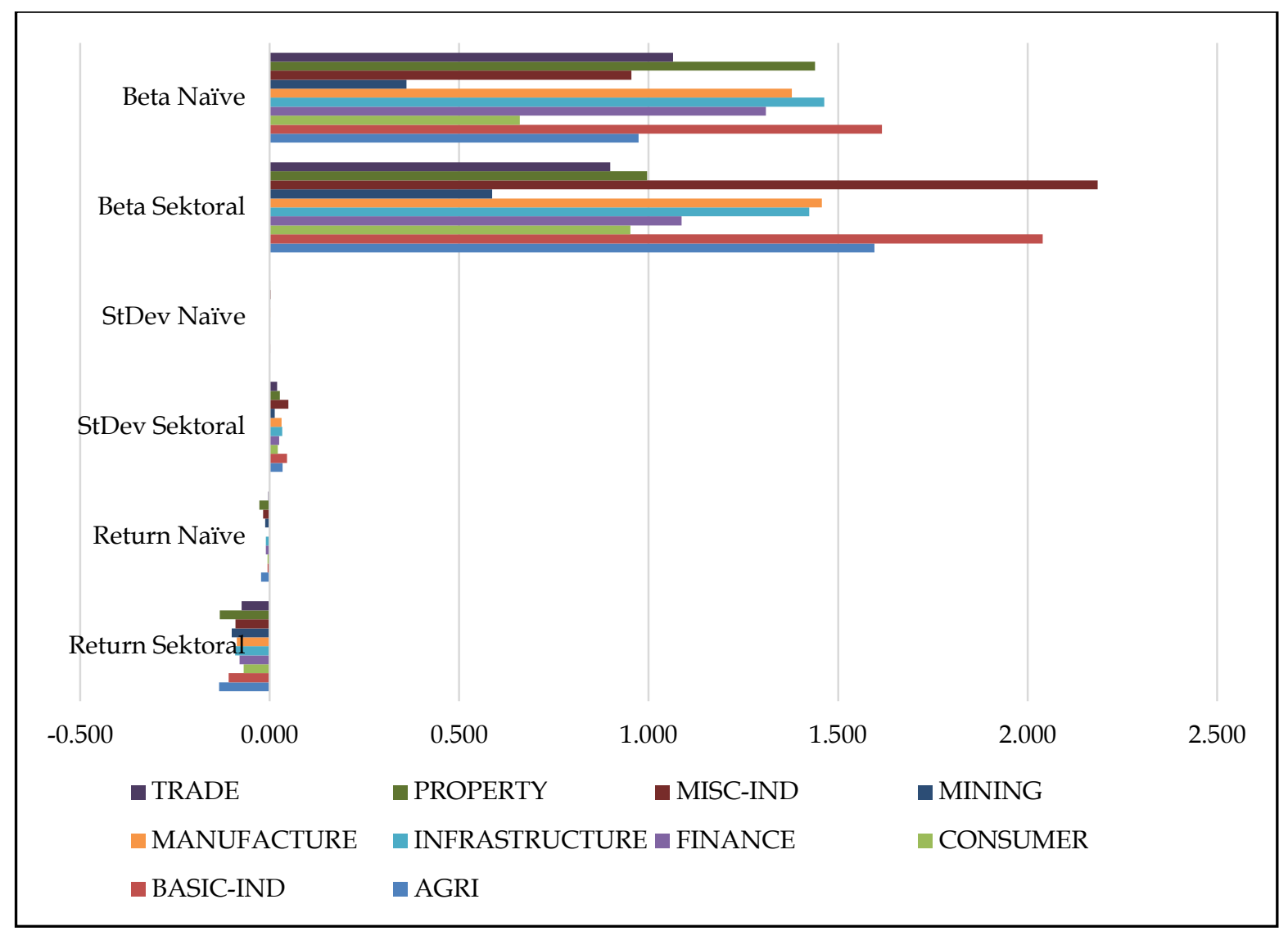

\subsubsection{Statistical Analysis}

Statistical analysis is used to examine the differences between returns, standard deviation and beta portfolio formed with naïve diversification modeling and those generated per sector in the Indonesia Stock Exchange. The table below shows portfolios formed with naïve diversification modeling provide lower capital loss compared to sectoral indexes. It also applies to standard deviation and beta of sectoral portfolios. It shows that the results of portfolio modeling based on naïve diversification show superior results compared to sectoral index.

Table 15. Paired Samples Statistics

\begin{tabular}{|l|l|r|r|r|r|}
\hline \multicolumn{2}{|c|}{} & Mean & N & Std. Deviation & $\begin{array}{c}\text { Std. Error } \\
\text { Mean }\end{array}$ \\
\hline \multirow{2}{*}{ Pair 1 } & Return_6M_Sektoral & -.0965000 & 10 & .02225733 & .00703839 \\
\cline { 2 - 6 } & Return_6M_Naive & -.0118000 & 10 & .00824352 & .00260683 \\
\hline \multirow{2}{*}{ Pair 2 } & StDev_Sektoral & .0297000 & 10 & .01118580 & .00353726 \\
\cline { 2 - 6 } & StDev_Naive & .0013000 & 10 & .00048305 & .00015275 \\
\hline Pair 3 & Beta_Sektoral & 1.3223000 & 10 & .51440927 & .16267050 \\
\cline { 2 - 6 } & Beta_Naive & 1.1220000 & 10 & .39552160 & .12507491 \\
\hline
\end{tabular}

Tabel 16. Paired Samples Correlations

\begin{tabular}{ll|r|r|r|} 
& & N & Correlation & Sig. \\
\hline Pair 1 & Return_6M_Sektoral \& Return_6M_Naive & 10 & .790 & .007 \\
\hline Pair 2 & StDev_Sektoral \& StDev_Naive & 10 & .635 & .048 \\
\hline Pair 3 & Beta_Sektoral \& Beta_Naive & 10 & .462 & .179 \\
\hline
\end{tabular}


The table above shows correlation between portfolios formed with naïve diversification modeling and the sectoral index. It can be seen that the close relationship is more visible in return compared to the standard deviation as a measure of risk. For low correlation beta per sector, as beta shows influence of the sector on capital market as a whole, it provides an overview of systematic risk of each sector. Statistical discrimination tests are carried out to see significance of differences of returns, standard deviation and beta portfolios formed per sector with naïve diversification modeling compared to the index per sector in the Indonesia Stock Exchange.

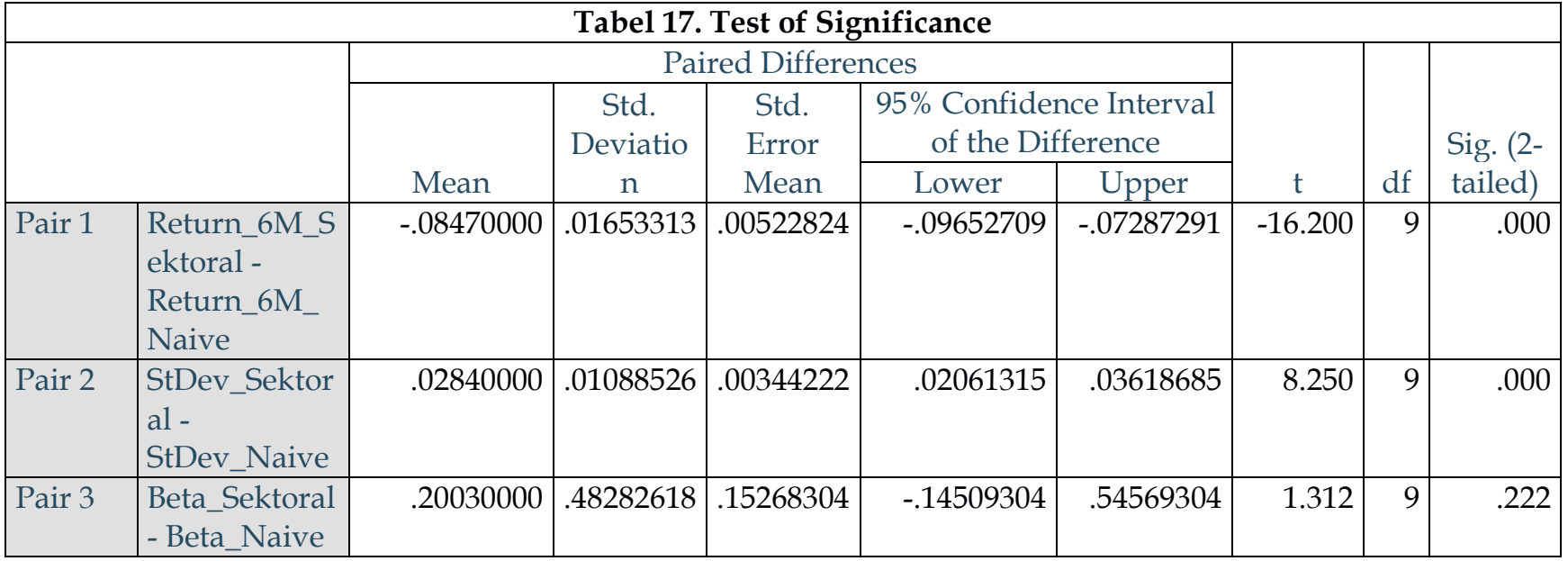

As shown in the previous table, significance test is similar to correlation table showing significance of differences between portfolios formed by naïve diversification modeling and index per sector. However, portfolio beta and beta per sector are not different because beta shows unsystematic risk associated with capital market and cannot be minimized by diversification.

\subsection{Discussion}

Referring to table 15, it appears that returns from both sectoral portfolios and portfolios based on naïve diversification show negative returns. However, sectoral portfolios provide greater losses than portfolios formed based on naïve diversification. Furthermore, for risk indicators with standard deviation measurements, it appears that standard deviation of sectoral portfolios is higher than standard deviation of naïve diversification-based portfolios. It shows that the difference between average expected return and realized return for sectoral portfolios is higher. In line with that, beta of sectoral portfolios is higher than beta portfolios based on naïve diversification. With the high beta, sectoral portfolios are more volatile or vulnerable to change along with market movements. Witiastuti (2012) in her research shows that optimal portfolio performance formed with single index and naïve diversification modeling is inferiority. This is different from the results shown by this study that the formation of portfolio based on naïve diversification shows superiority to its sectoral portfolio. Furthermore, Christiana \& Fadhila (2018) show that a portfolio with a single index minimizes risk, as it is minimizing risk, the return earned cannot exceed the returns offered by the market. The results of this study confirm that the formation of naïve diversificationbased portfolio not only minimizes risk but also minimizes losses that arise compared to portfolio formed per sector in the Indonesia Stock Exchange. For bearish market conditions, the formation of naïve diversification based portfolio indicates lower losses. 


\section{CONCLUSION}

The formation of portfolios with naïve diversification modeling refers to data published by the Indonesia Stock Exchange by emphasizing on distribution of the same proportion to the ten largest contributing companies per sector in the Indonesia Stock Exchange. The results of statistical tests show validation of systematic and unsystematic risks that occur in the Indonesia Stock Exchange. The results of the naïve portfolio modeling show condition of the Indonesia Stock Exchange in 2020 where most of capital markets experienced bearishness due to the pandemic. It can be ranked from the lowest to the highest loss as follows: manufacture, trade, basic industry, consumer, finance, infrastructure, mining, miscellaneous industry, agriculture and property. Because manufacturing sector is formed by other sectors, it can be concluded that in order to minimize investment losses due to bearish conditions, naïve portfolios can be carried out in five sectors with lower losses than other sectors, namely trade, basic industry, consumer, finance and infrastructure. The limitations of this study appear in the decline of return which will provide an indication of minimal losses when market conditions are bearish. Of course, during bullish market portfolio strategy implemented should follow alpha maximization, therefore further research is needed to align market timing strategy in portfolio selection.

\section{REFERENCES}

Christiana, I., \& Fadhila, N. (2018). Analisis Optimalisasi Portofolio Saham dengan Menggunakan Model Indeks Tunggal. Jurnal Riset Finansial Bisnis, 2(2), 51-60.

Hariasih, N. P., \& Wirama, D. G. (2016). Analisis Perbedaan Return Portofolio Berdasarkan Model Indeks Tunggal dan Portofolio Random. E-Jurnal Ekonomi dan Bisnis Universitas Udayana, 2951-2976.

Istiqlaliyah, H. (2016). Analisis Preferensi Investor Dalam Pengambilan Keputusan Investasi Menggunakan Metode Analytic Hierarchy Process. Nusantara of Engineering, 5358.

Lestari, W., \& Iramani, R. (2013). Persepsi Risiko dan Kecenderungan Risiko Investor Individu. Jurnal Keuangan dan Perbankan, 78-88.

Mudjiyono. (2012). Investasi Dalam Saham \& Obligasi dan Meminimimalisasi Risiko Sekuritas pada Pasar Modal Indonesia. Jurnal STIE Semarang, 1-18.

Putri, F., Bramanti, W. G., \& Hakim, M. S. (2017). Pengaruh Faktor kepribadian terhadap Toleransi Risiko Keputusan Investasi Saham. Jurnal Sains dan Seni ITS, 7-11.

Septyato, D., Sudarwan, \& Dewanto, I. J. (2016). Model Perilaku Syariah dalam Pengambilan Keputusan Investasi pada Investor Muslim di Bursa Efek Indonesia. Dinamika Global: Rebranding Keunggulan Kompetitif Berbasis Kearifan Lokal (pp. 425-437). jember: FEB-UNEJ.

Umam, N. K., Amalia, N., Alifah, N., Suffa, I., Aprilia, A., \& Wahyudi, H. D. (2017). Analisis Investasi Penentuan Portofolio Optimal Dengan Metode Indeks Tunggal di Bursa Efek Indonesia (Studi Komparatif Penggunaan Random Model pada Jakarta Islamic Index periode 2012-2015). Seminar Nasional Riset Manajemen \& Bisnis , (pp. 600613).

Witiastuti, R. S. (2012). Analisis Kinerja Portofolio: Pengujian Single Index Model dan Naive Diversification. Jurnal Dinamika Manajemen, 122-132. 
Yoga, W. W., \& Rikumahu, B. (2018). Prediksi Portofolio Optimal Menggunakan Model Markowitz dan Model Naive (Saham Yang Terdaftar pada Indeks LQ 45 Periode 2013-2017). E-Proceeding of Management, (pp. 1995-201). 